\title{
PERSEBARAN SEKTOR INFORMAL PEDAGANG KAKI LIMA MAKANAN DAN MINUMAN DI KOTA BUKITTINGGI
}

\author{
Nurul Fajri ${ }^{1}$, Yurni Suasti ${ }^{2}$, Ahyuni $^{2}$ \\ Program Studi Geografi \\ Fakultas Ilmu Sosial, Universitas Negeri Padang \\ e-mail: nurlfajrr@gmail.com
}

\begin{abstract}
Abstrak
Penelitian ini bertujuan untuk memetakan persebaran pedagang kaki lima berdasarkan (1) jenis makanan yang didagangkan (2) modal, (3) pendapatan, (4) tenaga kerja, (5) mendeskripsikan faktor pedagang kaki lima memilih lokasi berdagang. Penelitian ini menggunakan metode deskriptif dengan pendekatan kuantitatif. Penelitian ini menemukan: (1) pedagang kaki lima dominan berdagang sate dan sekoteng (2) Pada umumnya pedagang kaki lima bermodalkan Rp128.000 - Rp379.000 (3) Pada umumnya pedagang kaki lima memperoleh pendapatan Rp132.000 - Rp484.000 (4) pedagang kaki lima dominan memilih tenaga kerja berasal dari dalam rumah tangga (5) Faktor-faktor yang menyebabkan pedagang kaki lima makanan dan minuman di Kota Bukittinggi dalam memilih lokasi yaitu tempat dagangan yang mudah dijangkau dengan persentase $56,36 \%$.
\end{abstract}

Kata Kunci: Pedagang Kaki Lima, Makanan dan Minuman

\begin{abstract}
The purpose of this research are Portraying street food counter's distribution based on (1) food's kind (2) fund (3) income (4) workers (5) describe the factors of street food counter choosing the trading location. This research used descriptive method with quantitative approach. The result of the research are (1) street food counter are dominant in trading sate and sekoteng (2) Generally, the capital is between Rp128.000 - Rp379.000 (3) Generally, the income of street food counter is Rp132.000 Rp484.000 (4) Dominantly, street food counter involve family members as the workers. (5) Active crowd in the trade area is the factor of street food counter choose the location.
\end{abstract}

Keywords: Street Food Counter, Food and Beverage

\footnotetext{
${ }^{1}$ Mahasiswa Geografi Fakultas Ilmu Sosial Universitas Negeri Padang

${ }^{2}$ Dosen Geografi Fakultas Ilmu Sosial Universitas Negeri Padang. Pembimbing I; Dra. Yurni Suasti, M.Si. Pembimbing II; Ahyuni, ST, M.Si
} 


\section{PENDAHULUAN}

Kota Bukittinggi merupakan salah satu kota destinasi wisata di Indonesia yang banyak di kunjungi wisatawan, baik wisatawan mancanegara maupun wisatawan lokal. Terdapat berbagai wisata alam maupun wisata sejarah di Kota Bukittinggi seperti, Ngarai Sianok, Lobang Jepang, Benteng Fort de Kock dan Jam Gadang. Hal ini tentunya berpengaruh terhadap perkembangan kegiatan ekonomi di Kota Bukittinggi.Salah satu kegiatan ekonomi tersebut adalah dikenal dengan sektor informal.

Sektor informal merupakan salah satu sektor yang mempunyai kontribusi dalam kegiatan ekonomi. Konsep sektor informal merupakan status hubungan kerja yang terdiri atas pekerja mandiri dengan bantuan tenaga lepas, dan pekerja keluarga tanpa bayaran. Ciri-ciri lain pada sektor informal adalah dengan mudahnya menyerap tenaga kerja karena tidak mempunyai persyaratan penerimaan, seperti pendidikan formal maupun informal serta modal yang besar. Pada umumnya pekerja-pekerja dalam sektor informal adalah sebagian besar para wanita yang sudah menikah. Mereka masuk ke sektor informal karena tuntutan keluarga yang begitu besar selain itu juga mereka berusaha membebaskan diri dari kemiskinan (Arfida : 2003).

Menurut Rachbini (1994), ciri-ciri dari sektor informal tersebut adalah upah atau gaji yang tidak tetap, rendah, serta tidak cukup memadai. Produktivitasnya tidak maksimal karena sektor informal tidak menggunakan teknologi atau peralatan modern.
Keterampilan tenaga kerja kurang berkualitas relatif dibandingkan dengan tenaga kerja di sektor formal (Rachbini : 1994).

Disisi lain, sektor informal mampu menjadi tempat berlindung hingga mencapai 70 persen tenaga kerja di negara sedang berkembang.Hal ini karena sektor informal tidak membutuhkan skill yang tinggi bagi siapapun yang ingin mengais rezeki didalamnya (Rolis : 2013). Hasil penelitian membuktikan bahwa lapangan kerja sektor informal sebagai lapangan kerja yang banyak menyerap tenaga kerja umur produktif (Atika : 2009).

Sektor informal menjadi hal yang terus diperdebatkan. Sering kali pedagang kaki lima menjadi pihak yang salah karena berjualan di trotoar, taman kota, jembatan penyeberangan, bahkan badan jalan. Pemerintah berulang kali menertibkan lapak-lapak pedagang kaki lima (PKL) yang ditengarai mengganggu arus lalu lintas kota. Kadangkala, upaya penertiban ini mendapatkan perlawanan hingga terjadi bentrok antara pedagang dengan aparat keamanan pemerintah. Tidak jarang para PKL melakukan unjuk rasa dan memprotes kebijakan penertiban oleh pemerintah (Rukmana dalam Brotosunaryo : 2013).

Sebagai bagian dari sistem perekonomian di Indonesia, keberadaan sektor informal memiliki daya serap terhadap tenaga kerja yang cukup besar dan berperan sebagai sektor penyangga (buffer zone) yang sangat lentur dan terbuka. Sektor informal juga memiliki kaitan erat dengan jalur distribusi 
barang dan jasa di tingkat bawah, dan bahkan menjadi ujung tombak pemasaran yang potensial (Rolis : 2013)

Diantara sektor informal yang berkembang dibanyak tempat di kotakota adalah pedagang kaki lima. Tidak dipungkiri bahwa keberadaan PKL sering menimbulkan permasalahan dalam pembangunan kota, misalnya menimbulkan permasalahan kebersihan lingkungan dan keindahan, kesemrawutan lalu-lintas, potensi konflik yang relatif besar dan sebaginya. Disisi lain, PKL mempunyai kontribusi yang berarti bagi perekonomian masyarakat, terutama pada saat semakin sempitnya lapangan kerja (Utami : 2009).

Demikian juga halnya di Kota Bukittinggi, banyak ditemukan pedagang kaki lima yang secara ekonomi memberikan kontribusi yang besar. Untuk melihat tentang kontribusi sektor informal pedagang kaki lima makanan dan minuman, maka penelitian ini bertujuan untuk (1) memetakan persebaran PKL makanan dan minuman berdasarkan jenis makanan (2) memetakan persebaran PKL makanan dan minuman berdasarkan modal (3) memetakan persebaran PKL makanan dan minuman berdasarkan pendapatan (4) memetakan persebaran PKL makanan dan minuman berdasarkan tenaga kerja (5) mengetahui faktor yang menentukan PKL memilih lokasi berdagang.

\section{METODE PENELITIAN}

Jenis penelitian ini adalah deskriptif dengan pendekatan kuantitatif. Populasi penelitian ini adalah seluruh pedagang kaki lima makanan dan minuman yang berjumlah 124 orang dan tersebar di tujuh lokasi penelitian, yaitu: Monumen Polwan, Lapangan Wirabraja, Simpang Yarsi, Jalan Ahmad Yani, Jalan Abdul Rivai, Pasar Banto, dan Jalan Perintis Kemerdekaan. Sampel penelitian diambil secara random sampling dan jumlah sampel ditentukan menggunakan rumus Slovin dengan jumlah sampel 55 orang. Data dikumpulkan melalui wawancara dengan menggunakan kuisioner.

\section{HASIL DAN PEMBAHASAN}

\section{Jenis Makanan dan Minuman yang disediakan PKL di Kota Bukittinggi}

Gambar 1 memperlihatkan bahwa PKL makanan dan minuman terkosentrasi di pusat kota, yang tersebar di tujuh lokasi PKL yaitu: Monumen Polwan, Lapangan wirabraja, Simpang Yarsi, Jalan Ahmad Yani, Jalan Abdul Rivai, Pasar Banto dan Jalan Perintis Kemerdekaan. PKL makanan dan minuman melakukan kegiatan berdagang mulai dari sore sampai malam hari. 


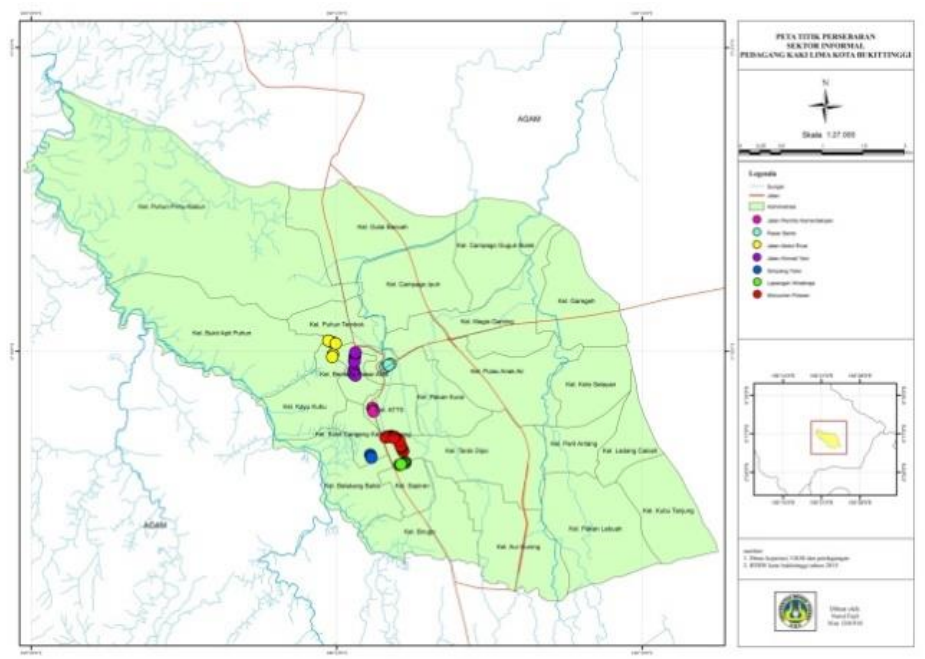

Gambar 1. Titik Persebaran Pedagang Kaki Lima Makanan dan Minuman di Kota Bukittinggi

Data tabel 1 memperlihatkan bahwa jenis makanan dan minuman yang disediakan PKL di Kota Bukittinggi cukup bervariasi.
Sehingga menjadikan salah satu daya tarik dibidang kuliner bagi wisatawan yang dating ke Kota Bukittinggi.

Tabel 1. Persentase Jenis Makan Yang Didagangkan PKL Di Kota Bukittinggi

\begin{tabular}{|c|c|c|c|c|c|c|c|c|c|c|c|c|c|c|c|c|c|}
\hline \multirow{3}{*}{ No. } & \multirow{3}{*}{$\begin{array}{c}\text { Jenis } \\
\text { Makanan }\end{array}$} & \multicolumn{14}{|c|}{ Titik PKL Makanan dan Minuman } & \multirow{2}{*}{\multicolumn{2}{|c|}{ Jumlah }} \\
\hline & & \multicolumn{2}{|c|}{$\begin{array}{c}\text { Monumen } \\
\text { Polwan }\end{array}$} & \multicolumn{2}{|c|}{$\begin{array}{l}\text { Lapangan } \\
\text { Wirabraja }\end{array}$} & \multicolumn{2}{|c|}{$\begin{array}{l}\text { Simpang } \\
\text { Yarsi }\end{array}$} & \multicolumn{2}{|c|}{$\begin{array}{c}\text { Jalan } \\
\text { Ahmad } \\
\text { Yani }\end{array}$} & \multicolumn{2}{|c|}{$\begin{array}{c}\text { Jalan Abdul } \\
\text { Rivai }\end{array}$} & \multicolumn{2}{|c|}{$\begin{array}{l}\text { Pasar } \\
\text { Banto }\end{array}$} & \multicolumn{2}{|c|}{$\begin{array}{c}\text { Jalan } \\
\text { Perintis } \\
\text { Kemerdeka } \\
\text { an } \\
\end{array}$} & & \\
\hline & & $\mathrm{f}$ & $\%$ & $\mathrm{f}$ & $\%$ & $\mathrm{f}$ & $\%$ & $\mathrm{f}$ & $\%$ & $\mathrm{f}$ & $\%$ & $\mathrm{f}$ & $\%$ & $\mathrm{f}$ & $\%$ & $\mathrm{f}$ & $\%$ \\
\hline 1. & Sekoteng & 3 & 5,45 & - & - & 1 & 1,82 & 3 & 5,45 & 1 & 1,82 & 1 & 1,82 & - & - & 9 & 16,36 \\
\hline 2. & Sate & 3 & 5,45 & 1 & 1,82 & 1 & 1,82 & 2 & 3,64 & 1 & 1,82 & - & - & 1 & 1,82 & 9 & 16,36 \\
\hline 3. & Pecel Lele & 2 & 3,64 & - & - & - & - & - & - & - & - & - & - & - & - & 2 & 3,64 \\
\hline 4. & Jus & - & - & 3 & 5,45 & - & - & - & - & - & - & - & - & - & - & 3 & 5,45 \\
\hline 5. & $\begin{array}{c}\text { Soto \& Nasi } \\
\text { Goreng }\end{array}$ & 2 & 3,64 & - & - & 1 & 1,82 & 4 & 7,27 & - & - & - & - & - & - & 7 & 12,73 \\
\hline 6. & Ampera & 1 & 1,82 & - & - & - & - & 1 & 1,82 & - & - & 1 & 1,82 & 1 & 1,82 & 4 & 7,27 \\
\hline 7. & $\begin{array}{c}\text { Mie } \\
\text { Surabaya }\end{array}$ & 1 & 1,82 & - & - & - & - & - & - & 1 & 1,82 & - & - & - & - & 2 & 3,64 \\
\hline 8. & Mie Rebus & 1 & 1,82 & - & - & - & - & - & - & - & - & - & - & 1 & 1,82 & 2 & 3,64 \\
\hline 9. & $\begin{array}{c}\text { Pempek } \\
\text { Ogan }\end{array}$ & 1 & 1,82 & - & - & - & - & - & - & - & - & - & - & - & - & 1 & 1,82 \\
\hline 10. & Lontong & 1 & 1,82 & - & - & - & - & 1 & 1,82 & - & - & - & - & - & - & 2 & 3,64 \\
\hline 11. & Teh Telur & 1 & 1,82 & - & - & - & - & - & - & - & - & - & - & - & - & 1 & 1,82 \\
\hline 12. & $\begin{array}{c}\text { Pisang } \\
\text { Panggang }\end{array}$ & 1 & 1,82 & - & - & - & - & - & - & - & - & - & - & - & - & 1 & 1,82 \\
\hline 13. & Air Aka & 1 & 1,82 & - & - & - & - & - & - & - & - & - & - & - & - & 1 & 1,82 \\
\hline 14. & Es Tebak & - & - & 1 & 1,82 & - & - & - & - & - & - & - & - & - & - & 1 & 1,82 \\
\hline 15. & $\begin{array}{c}\text { Mieso \& } \\
\text { Pangsit }\end{array}$ & - & - & 2 & 3,64 & - & - & - & - & 1 & 1,82 & 1 & 1,82 & - & - & 4 & 7,27 \\
\hline 16. & Susu Murni & - & - & 1 & 1,82 & - & - & - & - & - & - & - & - & - & - & 1 & 1,82 \\
\hline 17. & $\begin{array}{c}\text { Siomay } \\
\text { Bandung }\end{array}$ & - & - & - & - & 1 & 1,82 & - & - & - & - & - & - & - & - & 1 & 1,82 \\
\hline 18. & $\begin{array}{l}\text { Rujak } \\
\text { Cireng }\end{array}$ & - & - & - & - & - & - & - & - & 1 & 1,82 & - & - & - & - & 1 & 1,82 \\
\hline 19. & $\begin{array}{c}\text { Martabak } \\
\text { Telur Mini }\end{array}$ & - & - & - & - & - & - & - & - & 1 & 1,82 & - & - & - & - & 1 & 1,82 \\
\hline 20. & Ketoprak & - & - & - & - & - & - & - & - & 1 & 1,82 & - & - & - & - & 1 & 1,82 \\
\hline 21. & $\begin{array}{c}\text { Martabak } \\
\text { Mesir }\end{array}$ & - & - & - & - & - & - & - & - & - & - & 1 & 1,82 & - & - & 1 & 1,82 \\
\hline & Jumlah & 18 & 32,73 & 8 & 14,55 & 4 & 7,27 & 11 & 20 & 7 & 12,73 & 4 & 7,27 & 3 & 5,45 & 55 & 100 \\
\hline
\end{tabular}


Pada tabel 1 dapat dilihat jenis makanan yang terdapat ditujuh lokasi PKL yang terdapat di Kota Bukittinggi. Lokasi dengan jumlah PKL makanan dan minuman yang terbanyak terdapat di Monumen Polwan, yakni 32,73 persen. Sementara itu di enam lokasi lainnya, jumlah PKL makanan dan minuman berkisar antara 4,45 persen sampai 20 persen. Disamping itu, makanan dan minuman yang bervariasi juga terdapat di Monumen Polwan, yakni dari 21 jenis makanan dan minuman yang disediakan PKL di Kota Bukittinggi, yang tersedia di Monumen Polwan adalah sebanyak 12 jenis makanan dan minuman. Selanjutnya lokasi yang menyediakan makanan dan minuman yang bervariasi adalah di Jalan Abdul Rivai yakni, sebanyak 7 jenis makanan dan minuman.
Sedangkan di Lapangan Wirabraja, Simpang Yarsi, Jalan Ahmad Yani, Pasar Banto dan Jalan Perintis Kemerdekaan hanya menyediakan jenis makanan dan minuman antara 3 sampai 5 macam jenis makanan dan minuman

Dari berbagai macam jenis dagangan, pedagang kaki lima di Kota Bukittinggi cenderung menjual makanan dan minuman yang disajikan dalam keadaan hangat, seperti sate pada makanan dan sekoteng pada minuman. Faktor udara yang dingin turut mempengaruhi PKL dalam memilih dagangan.

\section{Modal Usaha PKL Makanan dan Minuman di Kota Bukittinggi \\ Modal usaha yang digunakan} PKL makanan dan minuman di Kota Bukittinggi cukup bervariasi. Dari yang bermodalkan tinggi hingga rendah.

Tabel 2.Persentase Modal PKL Makanan Dan Minuman Di Kota Bukittinggi Per Hari

\begin{tabular}{|c|c|c|c|c|c|c|c|c|c|c|c|c|c|c|c|c|c|}
\hline \multirow{3}{*}{ No. } & \multirow{3}{*}{$\begin{array}{l}\text { Modal } \\
(\mathrm{Rp})\end{array}$} & \multicolumn{14}{|c|}{ Titik PKL Makanan dan Minuman } & \multirow{2}{*}{\multicolumn{2}{|c|}{ Jumlah }} \\
\hline & & \multicolumn{2}{|c|}{$\begin{array}{l}\text { Monumen } \\
\text { Polwan }\end{array}$} & \multicolumn{2}{|c|}{$\begin{array}{l}\text { Lapangan } \\
\text { Wirabraja }\end{array}$} & \multicolumn{2}{|c|}{$\begin{array}{l}\text { Simpang } \\
\text { Yarsi }\end{array}$} & \multicolumn{2}{|c|}{$\begin{array}{c}\text { Jalan Ahmad } \\
\text { Yani }\end{array}$} & \multicolumn{2}{|c|}{$\begin{array}{c}\text { Jalan Abdul } \\
\text { Rivai }\end{array}$} & \multicolumn{2}{|c|}{$\begin{array}{l}\text { Pasar } \\
\text { Banto }\end{array}$} & \multicolumn{2}{|c|}{$\begin{array}{c}\text { Jalan } \\
\text { Perintis } \\
\text { Kemerde } \\
\text { kaan }\end{array}$} & & \\
\hline & & $\mathrm{f}$ & $\%$ & $\mathrm{f}$ & $\%$ & $\mathrm{f}$ & $\%$ & $\mathrm{f}$ & $\%$ & $\mathrm{f}$ & $\%$ & $\mathrm{f}$ & $\%$ & $\mathrm{f}$ & $\%$ & $\mathrm{f}$ & $\%$ \\
\hline 1. & $128.000-379.000$ & 11 & 20 & 3 & 5,45 & 3 & 5,45 & 7 & 12,73 & 5 & 9,09 & 1 & 1,82 & 2 & 3,64 & 32 & 58,18 \\
\hline 2. & $380.000-631.000$ & 2 & 3,64 & 2 & 3,64 & 1 & 1,82 & - & - & 2 & 3,64 & 1 & 1,82 & - & - & 8 & 14,55 \\
\hline 3. & $632.000-883.000$ & 2 & 3,64 & - & - & - & - & 1 & 1,82 & - & - & - & - & - & - & 3 & 5,45 \\
\hline 4. & $884.000-1.135 .000$ & 1 & 1,82 & 1 & 1,82 & - & - & 2 & 3,64 & - & - & 2 & 3,64 & - & - & 6 & 10,91 \\
\hline 5. & $1.136 .000-1.387 .000$ & 2 & 3,64 & - & - & - & - & - & - & - & - & - & - & - & - & 2 & 3,64 \\
\hline 6. & $1.388 .000-1.639 .000$ & - & - & - & - & - & - & 1 & 1,82 & - & - & - & - & 1 & 1,82 & 2 & 3,64 \\
\hline 7. & $1.640 .000-1.810 .000$ & - & - & 2 & 3,64 & - & - & - & - & - & - & - & - & - & - & 2 & 3,64 \\
\hline & Jumlah & 18 & 32,73 & 8 & 14,55 & 4 & 7,27 & 11 & 20 & 7 & 12,73 & 4 & 7,27 & 3 & 5,45 & 55 & 100 \\
\hline
\end{tabular}

Pada tabel 2 dapat dilihat modal yang digunakan per hari oleh PKL yang terdapat ditujuh lokasi PKL di Kota
Bukittinggi. Lokasi dengan modal perhari terbesar terdapat di Lapangan Wirabraja, yakni 3,64 persen. 
Disamping itu, pada umumnya PKL bermodalkan $128.000 \quad-\quad 379.000$ sebanyak 58,18 persen. Selanjutnya lokasi dengan modal per hari yang bervariasi adalah di Monumen Polwan, sebanyak 5 kelas interval modal. Sedangkan di enam kawasan PKL lainnya modal yang digunakan hanyaberkisar antara dua sampai empat kelas interval.

\section{Tenaga Kerja PKL Makanan dan Minuman di Kota Bukittinggi}

Tenaga kerja yang dipekerjakan dalam sektor informal PKL makanan dan minuman di Kota Bukittinggi cukup beragam. Peneliti membagi tenaga kerja PKL ke dalam tiga kelas yaitu yang berasal dari dalam rumah tangga, luar rumah tangga dan yang tidak memiliki tenaga kerja.

Tabel 4. Persentase Tenaga Kerja PKL Makanan Dan Minuman Di Kota Bukittinggii

\begin{tabular}{|c|c|c|c|c|c|c|c|c|c|c|c|c|c|c|c|c|c|}
\hline \multirow{3}{*}{ No. } & \multirow{3}{*}{ Tenaga Kerja } & \multicolumn{14}{|c|}{ Titik PKL Makanan dan Minuman } & \multirow{2}{*}{\multicolumn{2}{|c|}{ Jumlah }} \\
\hline & & \multicolumn{2}{|c|}{$\begin{array}{c}\text { Monumen } \\
\text { Polwan }\end{array}$} & \multicolumn{2}{|c|}{$\begin{array}{l}\text { Lapangan } \\
\text { Wirabraja }\end{array}$} & \multicolumn{2}{|c|}{$\begin{array}{l}\text { Simpan } \\
\text { g Yarsi }\end{array}$} & \multicolumn{2}{|c|}{$\begin{array}{c}\text { Jalan } \\
\text { Ahmad } \\
\text { Yani }\end{array}$} & \multicolumn{2}{|c|}{$\begin{array}{l}\text { Jalan } \\
\text { Abdul } \\
\text { Rivai }\end{array}$} & \multicolumn{2}{|c|}{$\begin{array}{l}\text { Pasar } \\
\text { Banto }\end{array}$} & \multicolumn{2}{|c|}{$\begin{array}{c}\text { Jalan } \\
\text { Perintis } \\
\text { Kemerd } \\
\text { ekaan }\end{array}$} & & \\
\hline & & $\mathrm{f}$ & $\%$ & $\mathrm{f}$ & $\%$ & $\mathrm{f}$ & $\%$ & $\mathrm{f}$ & $\%$ & $\mathrm{f}$ & $\%$ & $\mathrm{f}$ & $\%$ & $\mathrm{f}$ & $\%$ & $\mathrm{f}$ & $\%$ \\
\hline 1. & Dalam rumah tangga & 9 & 16,36 & 1 & 1,82 & 3 & 5,45 & 6 & 10,91 & 3 & 5,45 & 2 & 3,64 & 2 & 3,64 & 26 & 38,18 \\
\hline 2. & Luar rumah tangga & 6 & 10,91 & 6 & 10,91 & - & - & 4 & 7,27 & - & - & 1 & 1,82 & - & - & 17 & 25,45 \\
\hline 3. & Tidak ada & 3 & 5,45 & 1 & 1,82 & 1 & 1,82 & 1 & 1,82 & 4 & 7,27 & 1 & 1,82 & 1 & 1,82 & 12 & 16,36 \\
\hline & Jumlah & 18 & 32,73 & 8 & 14,55 & 4 & 7,27 & 11 & 20 & 7 & 12,73 & 4 & 7,27 & 3 & 5,45 & 55 & 100 \\
\hline
\end{tabular}

Pada tabel 4 dapat dilihat bahwa tenaga kerja PKL yang terdapat ditujuh lokasi PKL di Kota Bukittinggi. Lokasi dengan tenaga kerja terbanyak terdapat di Monumen Polwan, yakni 32,73 persen. Disamping itu, pada umumnya PKL menggunakan tenaga kerja yang berasal dari dalam rumah tangga, yakni sebanyak 38,18 persen, yaitu pada Monumen Polwan, Simpang Yarsi, Jalan Ahmad Yani, Pasar Banto dan Jalan Perintis Kemerdekaan. Sedangkan pada Lapangan Wirabraja PKL pada umunya lebih memilih tenaga kerja dari luar rumah tangga.

\section{Pendapatan PKL Makanan dan Minuman di Kota Bukittinggi}

Pendapatan yang diperoleh PKL makanan dan minuman di Kota Bukittinggi cukup bervariasi. Dari yang berpendapatan tinggi hingga rendah. 
Tabel 3. Persentase Modal PKL Makanan Dan Minuman Di Kota Bukittinggi Per Hari

\begin{tabular}{|c|c|c|c|c|c|c|c|c|c|c|c|c|c|c|c|c|c|}
\hline \multirow{3}{*}{ No. } & \multirow{3}{*}{$\begin{array}{c}\text { Pendapatan } \\
\text { (Rp) }\end{array}$} & \multicolumn{14}{|c|}{ Titik PKL Makanan dan Minuman } & \multirow{2}{*}{\multicolumn{2}{|c|}{ Jumlah }} \\
\hline & & \multicolumn{2}{|c|}{$\begin{array}{c}\text { Monumen } \\
\text { Polwan }\end{array}$} & \multicolumn{2}{|c|}{$\begin{array}{l}\text { Lapangan } \\
\text { Wirabraja }\end{array}$} & \multicolumn{2}{|c|}{$\begin{array}{l}\text { Simpan } \\
\text { g Yarsi }\end{array}$} & \multicolumn{2}{|c|}{$\begin{array}{c}\text { Jalan } \\
\text { Ahmad } \\
\text { Yani }\end{array}$} & \multicolumn{2}{|c|}{$\begin{array}{c}\text { Jalan } \\
\text { Abdul } \\
\text { Rivai }\end{array}$} & \multicolumn{2}{|c|}{$\begin{array}{l}\text { Pasar } \\
\text { Banto }\end{array}$} & \multicolumn{2}{|c|}{$\begin{array}{c}\text { Jalan } \\
\text { Perintis } \\
\text { Kemerd } \\
\text { ekaan }\end{array}$} & & \\
\hline & & $\mathrm{f}$ & $\%$ & $\mathrm{f}$ & $\%$ & $\mathrm{f}$ & $\%$ & $\mathrm{~F}$ & $\%$ & $\mathrm{f}$ & $\%$ & $\mathrm{f}$ & $\%$ & $\mathrm{f}$ & $\%$ & $\mathrm{f}$ & $\%$ \\
\hline 1. & $132.000-484.000$ & 4 & 7,27 & 1 & 1,82 & 3 & 5,45 & 7 & 12,73 & 5 & 9,09 & - & - & 1 & 1,82 & 21 & 38,18 \\
\hline 2. & $485.000-837.000$ & 6 & 10,91 & 4 & 7,27 & - & - & 1 & 1,82 & 1 & 1,82 & 1 & 1,82 & 1 & 1,82 & 14 & 25,45 \\
\hline 3. & $838.000-1.190 .000$ & 4 & 7,27 & 1 & 1,82 & - & - & 1 & 1,82 & 1 & 1,82 & 2 & 3,64 & - & - & 9 & 16,36 \\
\hline 4. & $1.191 .000-1.543 .000$ & 2 & 3,64 & 1 & 1,82 & 1 & 1,82 & - & - & - & - & - & - & 1 & 1,82 & 5 & 9,09 \\
\hline 5. & $1.544 .000-1.896 .000$ & 2 & 3,64 & 1 & 1,82 & - & - & - & - & - & - & 1 & 1,82 & - & - & 4 & 7,27 \\
\hline 6. & $1.897 .000-2.249 .000$ & - & - & - & - & - & - & - & - & - & - & - & - & - & - & - & - \\
\hline 7. & $2.250 .000-2.490 .000$ & - & - & - & - & - & - & 2 & 3,64 & - & - & - & - & - & - & 2 & 3,64 \\
\hline & Jumlah & 18 & 32,73 & 8 & 14,55 & 4 & 7,27 & 11 & 20 & 7 & 12,73 & 4 & 7,27 & 3 & 5,45 & 55 & 100 \\
\hline
\end{tabular}

Pada tabel 3 dapat dilihat pendapatan yang diperoleh per hari oleh PKL yang terdapat ditujuh lokasi PKL di Kota Bukittinggi. Lokasi dengan pendapatan perhari terbesar terdapat di Jalan Ahmad Yani, yakni 3,64 persen. Disamping itu, pada umumnya PKL memperoleh pendapatan 132.000 484.000 sebanyak 38,18 persen. Selanjutnya lokasi dengan modal per hari yang bervariasi adalah di Monumen Polwan dan Lapangan Wirabraja, sebanyak 5 kelas interval modal. Sedangkan di lima kawasan PKL lainnya yaitu: Simpang Yarsi, Jalan Ahmad Yani, Jalan Abdul Rivai, Pasar Banto dan Jalan Perintis Kemerdekaan pendapatan yang didapatkan hanya berkisar antara dua sampai tiga kelas interval.

\section{PENUTUP}

\section{Kesimpulan}

Dari hasil penelitian dan pembahasan yang telah dilakukan, maka dapat disimpulkan bahwa, Jenis makanan dan minuman yang disediakan PKL di tujuh lokasi, yakni Monumen Polwan, Lapangan Wirabraja, Simpang Yarsi, Jalan Ahmad Yani, Jalan Abdul Rivai, Pasar Banto dan Jalan Perintis Kemerdekaan cukup bervariasi. Dari 21 jenis makanan dan minuman, sate dan sekoteng tersedia di masing-masing lokasi PKL tersebut. Modal usaha PKL berkisar antara Rp128.000 Rp1.810.000 per hari dan yang terbanyak adalah dengan modal usaha Rp128.000 - Rp379.000 per hari. Dari besaran modal tersebut diperoleh pendapatan kotor antara Rp132.000 Rp2.490.000. Dalam melakukan usahanya, pada umumnya $(63,63 \%)$ PKL menggunakan tenaga kerja, yakni 38,18 persen tenaga kerja dalam rumah tangga dan 25,45 persen tenaga kerja luar rumah tangga. Dengan demikian PKL makanan dan minuman di Kota Bukittinggi secara ekonomi memberikan kontribusi yang besar 
terhadap pendapatan maupun penyerapan tenaga kerja.

\section{Saran}

Sarandari hasil penelitian yang ada, ditemukan bahwa sektor informal PKL secara ekonomi memberikan dampak yang besar terhadap pendapatan dan penyerapan tenaga kerja. Oleh karena itu sektor ini harus tetap dipertahankan dan dikembangkan keberadaannya, tetapi dengan tetap menjaga ketertiban, kebersihan dan tata ruang kota yang ada. Untuk itu diperlukan aturan yang jelas misalnya, perda tentang PKL yang mengatur tentang lokasi dan jam jualan PKL.

\section{DAFTAR PUSTAKA}

Arfida, BR. 2003. Ekonomi Sumber

Daya Manusia. Ghalia

Indonesia. Jakarta.

Atika, Dewi. 2009. Analisis Ekonomi

Usaha Rumah Tangga

Migran Sektor Informal

Brotosunaryo dan Hadi Wahyono.

2013. Strategi Penataan Dan

Pengembangan Sektor

Informal Kota Semarang

Rachbini, Didik J.1994. Ekonomi

Informal Perkotaan : Gejala

Involusi Gelombang Kedua.

Jakarta : PT. Pustaka LP3ES.

Ramli, Rusli. 1992.Sektor Informal

Perkotaan : Pedagang Kaki

Lima. Jakarta: Ind- Hill- co

Rolis, Moh Ilyas. 2013. Sektor

Informal Perkotaan Dan

Ikhtiar Pemberdayaannya
Utami, Trisni. 2009. Pemberdayaan

Komunitas Sektor Informal

Pedagang Kaki Lima (PKL),

Suatu Alternative

Penanggulangan Kemiskinan 